DOI: $10.14746 /$ por.2018.2.17

\title{
CZYTANIE ŚWIATA. HENRYK WANIEK - PISARZ, MALARZ, OUTSIDER
}

\author{
Kornelia Ć́niKLaK ${ }^{1}$ \\ (Uniwersytet im. Adama Mickiewicza w Poznaniu)
}

Słowa kluczowe: Henryk Waniek, Oneiron, Śląsk w literaturze, mistycyzm, pamięć

Keywords: Henryk Waniek, Oneiron, Silesia in literature, mysticism, memory

\begin{abstract}
Abstrakt: Kornelia Ćwiklak, CZYTANIE ŚWIATA. HENRYK WANIEK - PISARZ, MALARZ, OUTSIDER. „PORÓWNANIA” 2 (23), 2018. T. XXIII, S. 239-258. ISSN 1733-165X. Niniejszy tekst poświęcony został twórczości literackiej Henryka Wańka, artysty o niezwykle bogatym i spójnym dorobku literackim i malarskim, który scala idea odkrywania duchowego podłoża rzeczywistości. Dla właściwego zrozumienia jego sztuki ukazano ją w kontekście śląskiego undergroundu artystycznego lat sześćdziesiątych i siedemdziesiątych. Stawiam tezę, że Waniek łączy w swej twórczości (pozornie) przeciwstawne modele: outsiderski i powinnościowy, przy czym kierunek i zakres tego drugiego jest skutkiem autonomicznych decyzji twórczych. Pisarz z czasem coraz mocniej opowiada się po stronie modelu artysty będącego strażnikiem pamięci. Jednak istotne pozostaje nadal traktowanie sztuki jako drogi wtajemniczenia. Obydwie antagonistyczne postawy spotykają się w figurze outsidera, podążającego własną drogą przez Śląsk, który artysta uznał za centralne miejsce swojej twórczości.
\end{abstract}

Abstract: Kornelia Ćwiklak, READING THE WORLD. HENRYK WANIEK - AUTHOR, PAINTER, OUTSIDER. "PORÓWNANIA" 2 (23), 2018. Vol. XXIII, P. 239-258. ISSN 1733-165X This text is devoted to the works of Henryk Waniek, an artist of a remarkably rich and coherent literary and painting output merged by the idea of discovering the spiritual basis of our reality. The first part of this article discusses his activity as co-founder of the Oneiron Circle belonging to the Silesian artistic underground of the 1960s and 1970s, here related to as an essential context and prediction of his coming work. The second part analyses Waniek's prose, especially the categories of artistic memory, nature and consciousness. I propose the thesis that Waniek in his work brings together (seemingly) opposing models: an outsider model and an obligatory model. With time, the author takes the side of an artist as a memory guard more and more. However, it is crucial to treat art as

1 E-mail: cwiklak@amu.edu.pl 
initiation. Both attitudes are united in the figure of the outsider following his own path through Silesia which the artist considered to be the central point of his work.

Poniższy tekst poświęcony został twórczości literackiej Henryka Wańka, artysty osobnego, o niezwykle bogatym, przemyślanym i spójnym dorobku literackim i malarskim, który scala idea odkrywania duchowego podłoża rzeczywistości. Dla właściwego zrozumienia jego sztuki (zwłaszcza początków drogi twórczej) konieczne jest osadzenie jej w kontekście śląskiego undergroundu artystycznego lat sześćdziesiątych i siedemdziesiątych. Stawiam tezę, że Waniek łączy w swej twórczości (pozornie) przeciwstawne modele: outsiderski i powinnościowy, przy czym kierunek i zakres tego drugiego jest skutkiem całkowicie autonomicznych decyzji twórczych.

Outsideryzm, wiążący się z jednej strony z odrzuceniem modelu społecznych zobowiązań sztuki, forsowanego przez socjalistyczne państwo, a z drugiej strony z porzuceniem zarówno nurtów awangardowych, jak i - w późniejszym czasie ignorowaniem wymogów kultury popularnej, nie skutkował wszakże całkowitym unikaniem pewnego rodzaju zobowiązań sztuki. U Wańka ów model powinnościowy ukierunkowany został, po pierwsze, na uniwersalne zobowiązanie artysty i intelektualisty do poszukiwania prawdy, po drugie na kultywowanie pamięci o dawnych mieszkańcach Śląska i oddanie sprawiedliwości ich wkładowi w rozwój kulturowy krainy, którą artysta uznał za swą duchową ojczyznę i centralne miejsce swojej twórczości.

\section{Krąg Oneiron. „Wśród ludzi wolnych w kraju podległym”²}

Henryk Waniek z jednej strony postrzegany jest jako artysta osobny, wędrujący własnymi ścieżkami po Śląsku i jego bogatej, wielowątkowej, rozwijanej od stuleci kulturze wieloetnicznego i wielowyznaniowego pogranicza, z drugiej strony wszakże trudno zrozumieć fenomen jego twórczości malarskiej i pisarskiej bez kontekstu śląskiego podziemia artystycznego, które rozwijało się w latach sześćdziesiątych i siedemdziesiątych XX wieku.

Śląski underground epoki PRL-u to złożone zjawisko ${ }^{3}$, którego jeden z nurtów, skupiony wokół „Tajnej Kroniki Grupy Pięciu Osób” (Krąg Oneiron, zwany też

2 Przywołane w podtytule słowa pochodzą ze wspomnieniowego tekstu Zygmunta Stuchlika zamieszczonego pod takim tytułem w tomie zbiorowym Katowicki underground artystyczny po 1953 roku (Stuchlik 385).

3 Należy pamiętać o tym, że Krąg Oneiron miał poprzedników tworzących dekadę wcześniej artystyczne podziemie. W Katowicach, które dopiero co zostały przemianowane na Stalinogród, powstała grupa ST-53 (nazwa nawiązywała do miejsca i daty powstania oraz do nazwiska patrona). Tworzyli ją studenci katowickiej ASP wraz z przyjaciółmi z innych uczelni, m.in. Irena Bąk, Urszula Broll, Klaudiusz Jędrusik, Hilary Krzysztofiak, Maria Obremba, Zdzisław Stanek, Waldemar Świe- 
Ligą Spostrzeżeń Duchowych, działający w latach 1965-78 lub 1967-744), tworzyli oprócz Wańka katowiccy malarze Urszula Broll i Andrzej Urbanowicz, malarz i kompozytor Zygmunt Stuchlik oraz plastyk i reżyser Antoni Halor. Spotykali się oni regularnie na dyskusjach, przekładali prace niedostępne w języku polskim, kręcili filmy, stworzyli swego rodzaju czasopismo zatytułowane "Nowe Bezpretensjonalne Pismo Święte w Obrazkach” (zwane też Leksykonem bądź Encyklopedią), które Waniek uważa za pierwsze niezależne, podziemne pismo w PRL-u (dwa egzemplarze $\mathrm{w}$ formie teczki z rękopisami i pracami plastycznymi artystów krążyły w nieformalnym obiegu). Pracy artystycznej przyświecała idea pogłębienia duchowego, która prowadziła od studiowania przez członków grupy tekstów Carla Gustava Junga i odkrywania niewznawianych po wojnie ezoterycznych dzieł Gustava Meyrinka, przez tłumaczenie Tybetańskiej Księgi Umarłych, do praktykowania buddyzmu w pierwszej w Polsce wspólnocie zen. Powstała ona z inicjatywy Broll i Urbanowicza, przyczyniając się do rozszerzenia kręgu oddziaływania grupy.

Miejscem spotkań, a właściwie ośrodkiem działalności grupy było mieszkanie-pracownia Broll i Urbanowicza przy ul. Piastowskiej w Katowicach. Grono odwiedzających je osób wykraczało dalece poza pięcioosobowy krąg5. Tam artyści podjęli pracę wydawniczą, która co prawda zasięg odbiorców i nakłady miała skromne,

rzy i Krystyna Broll-Jarecka. Ich artystyczną biblią stała się Teoria widzenia Władysława Strzemińskiego (początkowo jej fragmenty jako skrypty wykładów udostępnił jego student, katowiczanin, Konrad Swinarski). Grupa była jedną z pierwszych form czysto artystycznego sprzeciwu wobec dominacji socrealizmu w polskiej sztuce. Funkcjonowała do 1958 roku. Zob. Zagrodzki oraz Urbanowicz 2006: 35. Inny artystyczny ensemble tego okresu stanowiła grupa Arkat (Artyści katowiccy, 1964), z którymi przez pewien czas współpracował Urbanowicz.

4 Słowo oneiron pochodzi z języka greckiego i oznacza 'sen'. Jak podaje Peter Mraß, autor tekstu zamieszczonego w katalogu wystawy (Oneiron. Ezoteryczny krąg artystów z Katowic, źródło elektroniczne), nieformalny związek artystów powstał w 1965 roku w pracowni Broll i Urbanowicza, zaś zakończył swą działalność w 1978 roku, gdy ten ostatni wyjechał do USA. Natomiast według słownika Polscy pisarze i badacze literatury przełomu XX i XXI wieku grupa działała od 1967 do 1974 roku (Henryk Waniek, źródło elektroniczne). (Słownik ten jest internetową wersją pierwszego tomu słownika biobibliograficznego o tym samym tytule, opublikowanego przez Wydawnictwo IBL PAN w 2011 roku). Rozbieżność co do datacji początków grupy rozstrzygną najpewniej słowa samego Urbanowicza, który napisał: „Od grudnia 1967 roku, regularniej niż poprzednio, zaczęło się spotykać grono przyjaciól, później nazwane Kręgiem ONEIRON” (Urbanowicz 1996: 87), podobnie Waniek: „ONEIRON, czyli owych pięć osób, które losowym zrządzeniem spotkały się wiosną 1967 roku” (Waniek 2006: 7) oraz: „Pomiędzy rokiem 1973 a 1974 aktywność zespołowa naszej grupy właściwie wygasła zupełnie. Nie zamarły koleżeńskie kontakty pomiędzy jej uczestnikami, ale zabrakło treści i motywacji do dalszych działań kolektywnych" (Waniek 2006: 10).

5 Do owej „galerii sprzymierzeńców” Waniek zaliczył kilkanaście osób, w tym: Zdzisława Beksińskiego („,wówczas jeszcze mało znany malarz z Sanoka”, z którym Urbanowicza połączy wieloletnia korespondencja), Andrzeja Kostołowskiego („krytyk sztuki z Poznania”), artystów Hannę Keyhę i Zygmunta Lisa, poetów Ryszarda Krynickiego i Jerzego Illga, a także Stefana Morawskiego, Jerzego Prokopiuka i Jacka Woźniakowskiego (Waniek 2006: 7). Urbanowicz wśród częstych gości wymienia Henryka Mikołaja Góreckiego, ponadto Tadeusza Sławka i Józefa Szajnę (Urbanowicz 2006: 41, 45, 49). Trudno zliczyć wszystkich znakomitych twórców, którzy odwiedzali pracownię Urbanowiczów. 
pozwalające odpowiadać jedynie na potrzeby grona przyjaciół i znajomych (książki przepisywano na maszynie), lecz ciężar gatunkowy dzieł i nazwiska tłumaczy były pierwszorzędne ${ }^{6}$.

Warto zwrócić uwagę na to, że działalność katowickich twórców była w środowisku artystycznym atrakcyjną alternatywą dla rzeczywistości okresu PRL-owskiej małej stabilizacji, przytłaczającej wszechobecną kontrolą i cenzurą, a także konformizmem postaw i brakiem perspektyw zawodowych i egzystencjalnych ${ }^{7}$. Jak można przeczytać w katalogu wystawy Oneiron. Ezoteryczny krąg artystów z Katowic,

Grupa ONEIRON stworzyła wyłom w powszedniości lat 60. Pięcioosobowa zrazu grupa skierowana była na ezoterykę, zakładającą istnienie ukrytego źródła, do którego dociera się, idąc w górę rzeki. Tropy prowadzą przez terytoria nowoczesnego wyrazu artystycznego, ale także jego wyklętych rejonów oraz filozofii ducha. Grupa ONEIRON dla kultury polskiej odkryła wiele światów artystycznych, w tym mit czeskiej Pragi oraz alchemii i wiedzy tajemnej, choć podlegającej artystycznej racjonalizacji. Po raz pierwszy w Polsce dogłębnie zainteresowała się buddyzmem-zen (Oneiron. Ezoteryczny krag artystów z Katowic, źródło elektroniczne) $)^{8}$.

Sam Waniek, wspominając powstanie Kręgu Oneiron, zwracał uwagę zarówno na realia życia w PRL-u, jak i na specyfikę sytuacji regionu w tym okresie: „Górny Śląsk, jedyny ocalały kawałek całego Śląska, [...] była to najsilniej kontrolowana, eksploatowana i jawnie pogardzana część Polski Ludowej. Kulturalnie oddalona od reszty kraju o setki lat. Obca" (Waniek 2006: 4). Odpowiedzią artystów na duchowe i intelektualne wyjałowienie czasów, w jakich przyszło im żyć i tworzyć, było utwo-

6 Były to głównie publikacje z zakresu kulturo- i religioznawstwa, które nie miały szans ukazać się w oficjalnym obiegu, m.in.: pierwszy polski przekład książki Mircei Eliadego Alchemicy $i$ kowale, Carla Gustava Junga Psychologia a alchemia, Gustava Rene Hocke'a, Świat jako labirynt, Droga Biatych Obłoków Lamy Anagariki Govindy. Działalność wydawnicza trwała w latach 1965-1973. Inny przykład: w 1967 Antoni Halor wydał w pięciu egzemplarzach nowelę Zegarmistrz Gustava Meyrincka (metodą, która można nazwać „zrób to sam” - własny przekład, ilustracje, druk i oprawa) (Urbanowicz 2006: 53). W późniejszym okresie ukazały się przekłady m.in. traktatu religijnego Księga śmierci. Bardo Thödol (przeł. A. Urbanowicz, H. Waniek, wyd. jako rękopis, Galeria Autorska J. Solińskiego i J. Kaji, Bydgoszcz 1983); I ching - Ksiegga zmian (przeł. A. Urbanowicz, H. Waniek, Dom Kultury „Agora”, Bydgoszcz 1985) oraz Aldous Huxley, Drzwi percepcji. Niebo i piekło (przeł. P. Kołyszko, H. Waniek, Wyd. Przedświt, Warszawa 1991).

7 „Nie byliśmy w żaden sposób związani z systemem oficjalnym, a nawet chwilami czuliśmy jego grożący palec. Naszym wyborem była bowiem niezależność, a nie polityczny czy zawodowy koniunkturalizm. Stąd również podtrzymywaliśmy alians z ruchem hippies i jego łagodną rewolucyjnością" - wspominał Waniek (Waniek 2006: 10). Nie tylko jednak rzeczywistość PRL-u, ale i zachodnia cywilizacja oceniane były krytycznie: „Wszyscy byliśmy wtedy zawiedzeni Zachodem. Kto mógł, jechał do Indii, a najlepiej do Nepalu. Przede wszystkim hippies, programowo bezdomni. Były to lata ich kulminacji" (Waniek 1997: 80).

8 Niewymieniony z nazwiska autor tych słów nawiązuje wyraźnie do tekstu H. Wańka pt. Mistyczna aura Sląsa (Waniek 2006). 
rzenie własnego środowiska, towarzyskiego kręgu twórców, połączonych zbliżoną wizją sztuki:

Wiedzieliśmy, że trzeba się z tej opresji ratować. Otaczający nas nadmiar materializmu, wraz z całym zakłamaniem sloganów komunistycznych, sam pchał nas w kierunku przeciwnym. Chodziło nam o to, co dla tamtego systemu było nie do przyjęcia. Można powiedzieć, że pracowaliśmy nad mapą ucieczki do prywatnej duchowości (Waniek 2006: 4).

Droga duchowego rozwoju, odzwierciedlająca się w ich sztuce, nie oznaczała jednak eskapizmu, próby ucieczki od ówczesnej rzeczywistości, lecz przeciwnie wynikała z głębokiej potrzeby zrozumienia rzeczywistości i odkrywania jej sensu. Grupa odrzucała oficjalną sztukę Polski Ludowej, a poszukiwanie alternatywy prowadziło ją od twórczej recepcji surrealizmu do eksplorowania tradycji mistycznej ${ }^{9}$. W przy padku Wańka oznaczało to skupienie się na pismach niemieckich mistyków śląskich. Wynikająca z tych poszukiwań formuła sztuki zbliża ją do koncepcji wtajemniczenia bądź każe rozumieć jako narzędzie rozszyfrowania ukrytych znaczeń świata. Rzec można, że sztuka wedle tej koncepcji to maszyna deszyfrująca.

O trafności powyższego rozpoznania świadczą między innymi duchowi patroni katowickich artystów, których twórczością zaczęli się inspirować. Należeli do nich, oprócz wymienionych już Junga i Meyrinka, Alfred Kubin, Rudolf Steiner, Hermann Hesse, André Breton, Frances Yates, Gustav René-Hocke, Karl-Wolfgang Tröger, z których bodaj najważniejszym okazał się Breton (o jego wpływie na ich poglądy i aktywności piszę poniżej). Tym samym artystyczne i intelektualne poszukiwania kręgu Oneiron stały się impulsem umożliwiającym twórcze przyswojenie przez polską kulturę i sztukę idei rozwijanych kilka(naście) lat wcześniej na zachodzie Europy przez przedstawicieli surrealizmu.

Celem działań grupy stało się poszukiwanie nowej świadomości, przemiana duchowa i rewolucja wewnętrzna (Urbanowicz 2004: 91) ${ }^{10}$. Prowadzić do tego miał cykl samokształceniowych spotkań, dyskusji i twórczych działań, wśród których znalazły się dadaistyczne happeningi (np. Wernisaż dynamiczny, Męczeństwo i śmierć Joanny d'Arc, Salvador Dali), pokazy, misteria, wspólnie tworzone filmy ${ }^{11}$ oraz zasługujący na szczególną uwagę cykl Czarnych Kart, który stał się manifestem ar-

9 Jednocześnie artysta dystansował się od taniej, merkantylnej wersji ezoteryki spod znaku ulicznych nauczycieli, azjatyckiego jedzenia i trociczek: „Już wtedy można było - jeśli tylko ktoś chciał - zorientować się, że większość obietnic to stara tandeta intelektualna w nowym opakowaniu" (Waniek 1997: 74).

10 W przywoływanej publikacji pt. Katowicki underground artystyczny po 1953 roku znajduje się najpełniejszy zbiór materiałów poświęconych działalności Kręgu Oneiron.

11 Jedną z pierwszych realizacji był surrealistyczny film Chrysopea (1965-1966, reż. Antoni Halor, scenariusz i scenografia Andrzej Urbanowicz, muzyka Zygmunt Stuchlik) (Urbanowicz 2006: 45). 
tystycznym grupy ${ }^{12}$. Niezależnie od wspólnych przedsięwzięć artyści prowadzili intensywnie indywidualną działalność twórczą, uczestnicząc w wystawach, odczytach oraz różnego rodzaju happeningach (Waniek 2006: 8) ${ }^{13}$.

Jak uważa Peter Mraß, idea zbioru Czarnych Kart była zapewne kontynuacją myśli Bretona o związku sztuki i magii (Mraß 13). Twierdził on, iż stłumiona przez rozwój cywilizacyjny magia została ponownie odkryta przez surrealizm. Postulował, by jej rolę przejęła sztuka imaginatywna, „wyzwolona z estetyki, etyki i ideologii społeczeństwa mieszczańskiego" (Mraß 13), przy czym szczególne znaczenie przypisywał malarstwu i poezji. W Drugim manifeście surrealizmu (1930) Breton postulował "okultację surrealizmu" i uwydatniał rolę surrealistycznych "gier towarzyskich”, to jest kolektywnych rysunków prowadzących do „możliwości utworzenia wspólnej myśli" (Breton 141) ${ }^{14}$. Na wpływ surrealizmu Bretona wskazuje bezpośrednio Waniek: "Gdyby do tego naszego przedsięwzięcia szukać jakiejś paranteli, to może byłyby to echa surrealizmu, który zresztą zgodnie respektowaliśmy. Szczególnie jego późną fazę, gdy w latach pięćdziesiątych Breton uległ czarowi okultyzmu i magii..." (Waniek 2004: 177) ${ }^{15}$. Myśl o ścisłym związku sztuki i magii pojawiała się wówczas często w środowisku artystycznym, o czym świadczą między innymi słowa Andrzeja Kostołowskiego, jakie wygłosił podczas I Katowickich Spotkań Twórców i Teoretyków Sztuki w 1968 roku: „Kim jest artysta, który próbuje określić swój status przez kontakt z wszechrzeczami? Czym jest jego dzieło?... Czy nie jest on okultystą, jedynie tajemnie i intuicyjnie kontaktującym się z wszechświatem?" (Urbanowicz 2006: 65).

Twórców Kręgu Oneiron, podobnie jak surrealistów, interesowała problematyka wyobraźni i snu ${ }^{16}$. Warto $\mathrm{w}$ tym kontekście przypomnieć, że do najważniej-

12 Współtworzony przez pięcioro artystów Cykl Czarnych Kart powstawał od grudnia 1967 do października 1969 roku. Składały się nań obrazy, rysunki, symbole graficzne, rękopisy tekstów i sentencji. Jak wspomina Waniek, "ten nieco dadaistyczny leksykon [...] był polem naszego wyznania, tak ideowego, jak estetycznego; a równocześnie dialogu i nauką zgodnej pracy" (Waniek 2006: 8).

13 Autor zwraca tu uwagę na prywatną formułę kooperacji artystów: „...przez długi czas nasz związek miał charakter nie tyle konspiracyjny, co «wewnętrzny». Nie było - do pewnej chwili - potrzeby zewnętrznego manifestowania naszego sojuszu. Widoczny stawał się on dla tych, którzy z różnych powodów wchodzili z nami w bliższe relacje" (Waniek 2006: 8).

14 W 1930 roku Bretona fascynowała przede wszystkim astrologia, między innymi sporządził on szczegółowy własny horoskop. Natomiast w latach czterdziestych i pięćdziesiątych intensywnie studiował alchemię i magię, czego wynikiem było opublikowanie w 1957 roku Sztuki magicznej (Mraß 26).

15 Na osobiste powiązanie z ruchem paryskich surrealistów wskazuje Waniek, opisujący swe spotkanie z Hansem Bellmerem (1902-1975) w paryskim mieszkaniu malarza surrealisty Maxa Ernsta jesienią 1970 roku. Artysta urodził się w Katowicach i tam mieszkał do dwudziestego pierwszego roku życia (Waniek 1994). Zanim rodzina wyemigrowała, Bellmer miał w rodzinnym mieście pierwszą wystawę swych prac. Członkowie Kręgu Oneiron założyli Towarzystwo Bellmer.

16 W Manifeście surrealizmu (1924) dużo miejsca zajmują rozważania nad funkcją i znaczeniem wyobraźni oraz snu. Breton odcina się w nim od poglądów pozytywistycznych i estetyki realizmu, które traktuje jako "zaprzeczenie wzlotu intelektualnego i moralnego". Opowiada się po stronie wyobraźni, cudowności, odwołań do dzieciństwa i znaczenia przypadku (Breton 55). 
szych założeń surrealizmu w malarstwie należało wizualne wyrażanie percepcji wewnętrznej. Jego przedstawicieli fascynowało to, co dzieje się we wnętrzu człowieka, lecz poza jego świadomym wpływem. Czerpali swobodnie z Freudowskiej psychoanalizy. Breton domagał się uznania dla wyobraźni i podświadomości, które miały warunkować pełną i nieskrępowaną ekspresję oraz rozwój możliwości twórczych człowieka. Charakterystyczna dla surrealistów była ponadto postawa buntu i wolności artysty oraz poczucie absolutnego nowatorstwa, co nie przeszkadzało im sięgać do nieodległych doświadczeń dadaizmu, badających rolę przypadku i kombinatoryki. Jedną z ważniejszych koncepcji twórczych była idea pisma automatycznego.

Przyjmując podobne założenia, Urbanowicz zaproponował stworzenie symbolicznego Leksykonu, czyli cyklu Czarnych Kart, których pomysł nawiązywał do wykonywanych przez surrealistów kolektywnie anonimowych i imaginatywnych rysunków ${ }^{17}$. Owo „nowe pismo obrazkowe” czy też „nowy Chaos obrazów” to zestaw czarnych kart $(70 \times 70 \mathrm{~cm})$ odpowiadających poszczególnym literom alfabetu, które artyści niezależnie od siebie zapełniali piktogramami w kolorze białym, srebrnym lub złotym (każda karta była tworem 3-4 autorów). W efekcie miał powstać „wielki, monochromatyczny fresk, rozłożony na dwudziestu kilku kwadratowych fragmentach" (Waniek 2004: 176). Mraß wskazuje różnorodne źródła inspiracji:

W fascynującą magicznością przestrzeń cyklu Czarnych Kart wplecione zostały różne myśli, koncepcje i wizje: psychologia archetypów i symboli Junga, wizja świata symbolicznego Cassirera, mitologiczne kosmogonie, związki alfabetu i kabały, idea kosmicznego człowieka, makro- i mikrokosmosu, symbolika mandali i misterium wizualizacji hinduskiej tantry, alchemiczny proces duchowego rozwoju człowieka, a także dadaistyczna kpina i szyderstwo. Kształt artystycznej wypowiedzi zrealizowany na płaszczyźnie Czarnych Kart wyznaczyła surrealistyczna forma magiczności sztuki (Mraß 23).

$\mathrm{Na}$ jeszcze inną intelektualną motywację cyklu Kart, którego powstawanie łączyło wszak myśl porządkującą z wpływem przypadku, wskazuje jego pomysłodawca, Urbanowicz. Bliska jest mu idea chaosu pojmowanego jako pierwotna siła twórcza: „Tłumienie chaosu powoduje zahamowanie zdolności twórczych, a tym

17 „Piktogramy na Czarnych Kartach przypominają rysunki cadavre exquis (wyborny trup). Była to dawna zabawa dziecięca zaadaptowana około 1925 roku przez surrealistów, podczas której 3-4 osoby tworzyły wspólny rysunek. Dzieła te miały uświadomić uczestnikom gry powiązania świata zewnętrznego z wewnętrznym. Surrealistów interesował sam proces twórczy, automatyzm, wyłączenie umysłu krytycznego i otwarcie jego zdolności metaforycznych. Rysunki cadavre exquis, interpretowane w kategoriach psychoanalizy Sigmunda Freuda (1856-1939), koncepcji popędów i analizy marzeń sennych, były dla surrealistów symbolicznym kluczem do świata nieświadomości" (Mraß 18). Mogły też nawiązywać do znanych na Śląsku gier dydaktycznych, polegających na wyszukiwaniu wyrazów zaczynających się na literę podaną przez nauczyciela. Szczegółowe omówienie projektu opublikował Urbanowicz (Urbanowicz 1996: 87-91). 
samym opór wobec wyobraźni" (Urbanowicz 1996: 89). Fundamentalne dla wszelkiej twórczości znaczenie chaosu pojmuje tak jak Terrence McKenna, który uważa, że:

Proces tworzenia kultury zależy od tego, czy ulegniemy powabowi chaosu. [...] Wyobraźnia to chaos, wyławiamy z niej nowe formy. Akt twórczy to zarzucenie ludzkiej fantazji w ocean chaosu, na którym się unosimy, i próba wydobycia z niego pomysłów... Wierzę, że chaos może stać się wspaniałą skarbnicą uporządkowanego piękna (McKenna, cyt. za: Urbanowicz 1996: 90).

Podsumowując ten etap twórczej biografii artysty, warto zwrócić uwagę na formacyjną rolę Kręgu Oneiron i jego wpływ na dalszą działalność poszczególnych przedstawicieli, co potwierdzają słowa Wańka: „Cały ten okres, zamykający się $\mathrm{w}$ niecałym dziesięcioleciu, można rozumieć jako przeciągłą inicjację w sprawy lokalne i uniwersalne, z której czerpiemy do dzisiaj" (Waniek 2006:5) oraz Urbanowicza: „Echa nadal rezonują w czasie i przestrzeni” (Urbanowicz 2006: 31).

Z czasem Waniek, poszukując nowych środków wyrazu, rozszerzył pole działalności twórczej, przechodząc od malarstwa (którego nigdy nie porzucił) do publicystyki, eseju i - od połowy lat osiemdziesiątych - literatury pięknej. Kolejne pytania i zagadnienia wynikają z zarysowanego tu charakteru pierwszego okresu twórczości Wańka i wiążą się ze sposobem, w jaki artysta skrystalizowane wówczas idee i tematy eksplorował później na gruncie literatury. Czy zarysowane wtedy problemy zostały rozwinięte czy też porzucone na rzecz innych, nowych? Jak w późniejszym, dojrzałym okresie twórczości rozumiał on społeczną rolę artysty?

\section{2. "Powołaniem artysty jest obcowanie z tym, co ukryte". Artystyczny modus operandi w prozie Henryka Wańka ${ }^{18}$}

Waniek jest nie tylko artystą wielu talentów, z powodzeniem uprawiającym malarstwo, grafikę, publicystykę, przekład, esej i powieściopisarstwo, ale też twórcą niezwykle pracowitym i płodnym ${ }^{19}$. Centralne znaczenie $\mathrm{w}$ jego pisarstwie mają

18 Zacytowane w tytule słowa pochodzą z przywoływanego już artykułu (Waniek 2006: 5).

19 Pomijam obszerny dorobek plastyczny, który nie jest przedmiotem tego szkicu, by wymienić opublikowane dotąd następujące książki eseistyczne i powieści Wańka: Dziady berlińskie (1984), Hermes w Górach Śląskich (1994), Opis podróży mistycznej z Oświęcimia do Zgorzelca (1996), Pitagoras na trawie (1997), Inny Hermes (2001), Finis Silesiae (2003, nagroda Fundacji Kultury „Promocja”, finał nagrody Nike), Martwa natura z niczym. Szkice z lat 1990-2004 (2004), Wyprzedaż duchów (2007), Sprawa Hermesa (2007), Katowice-blues czyli Kattowitzer-Polka (2010), Notatnik i modlitewnik drogowy (2013), Jak Johannes Kepler jadąc do Żagania na Śląsku zahaczyt o księżyc (2015), Cmentarz nieśmiertelnych (2015), Obcy w kraju urodzenia (2016), Miasto niebieskich tramwajów (2017), Szalone życie Macieja Z. (2018). Osobnego studium wymagałaby zapewne kwestia korespondencji między twórczością plastyczną 
kwestie takie jak pamięć i miejsce przeszłości w teraźniejszości, natura i krajobraz, mistycyzm i mit. By przybliżyć się do ich wyjaśnienia, należałoby przeanalizować obecne w książkach Wańka literackie wyznaczniki konstrukcji podmiotu i pamięci, mityzacji oraz formy gatunkowej. Istotne będą również te fragmenty tekstów, które wskazują na świadomość twórczą pisarza.

\section{1.}

Podmiot-bohater utworów Wańka to wędrowiec, eksplorer poszukujący prawdy o krainie, która go zafascynowała. Zapuścił w śląskiej ziemi korzenie dzięki własnym wyborom i zaangażowaniu w poznawanie przeszłości tego regionu. Pasja krajoznawcza, wędrówki, lektury, wreszcie zgromadzona wiedza sprawiają, że staje się on Ślązakiem z umiłowania, lepiej - jak pisze Wojciech Browarny - rozumiejącym tę krainę niż niejeden jej obecny mieszkaniec:

Emocjonalne zaangażowanie w kulturowy przekaz Sudetów i fascynacja jego twórcami prowadzi podmiot Wańka do empatii dla poprzedników, przekraczającej ich narodowe czy polityczne lojalności, a nawet dalej - do poczucia ponadczasowej wspólnoty ducha z tymi, i tylko tymi, którzy pojmując tutejsze dziedzictwo, potrafili je zachować i powiększać (Browarny 247).

Jedną z podstawowych kwestii poddawaną ocenie w esejach Wańka jest stosunek ludzi osiadłych na Śląsku po wojnie do jego historycznej spuścizny. Narrator surowo osądza każde naruszenie kulturowego bądź naturalnego dziedzictwa. Tropi i wytyka dowody destrukcji dziedzictwa materialnego, jak i zafałszowania

i literacką Wańka. Wstępnie można stwierdzić szereg analogii na poziomie tematyki, pojedynczych motywów i symboliki jego dzieł. Istnieją obrazy inspirowane treścią książek, które można by uznać za przykład przekładu intersemiotycznego bądź po prostu za ilustracje do książek, jak np. znajdujące się $\mathrm{w}$ posiadaniu piszącej te słowa akwarele wzorowane na fotografiach Karla Franza Klosego, którego album Die Schlesische Landschaft (Breslau 1942) stał się punktem wyjścia do historii opowiedzianej w powieści Finis Silesiae (kilka z nich zamieszczono w książce). Tworzenie cyklu akwarel towarzyszyło powstawaniu powieści, o czym świadczą widniejące na nich tytuły i daty powstania: Nach Karl Franz Klose (87) Landeskrone bei Görlitz, September 1998 (Łagów koło Zgorzelca); Schwedeldorf, Henryk Waniek, Aug. 2003. Obraz ukazujący zmrok zapadający nad wioską Szalejów przedstawia dokładnie tę samą perspektywę co wykonana około 60 lat wcześniej fotografia. Podobnie widok wzniesienia o nazwie Landeskrone przedstawia na pracy Wańka bliźniaczy punkt widzenia co na fotografii Klosego. Artysta przygląda się w powieści i na obrazie temu, co zmieniło się w krajobrazie (nie ma już np. klonu, spod którego przed laty wykonane zostało zdjęcie w Schwedeldorf), ale też wykonując dziś akwarele, ukazuje ponadczasowe piękno Śląska. Można sądzić, że dąży do zatarcia różnicy czasu i wbrew biegowi historii pragnie przywrócić zerwaną ciągłość śląskiej kultury. Innym przykładem tego, jak malarstwo Wańka rezonuje w jego twórczości literackiej, jest obecna w Obcym w kraju urodzenia poboczna postać malarza Juszczaka, będąca - jak można się domyślić - alter ego autora i nabierająca istotnego znaczenia w finale powieści, gdy dopełnia się proces uzyskiwania samoświadomości przez głównego bohatera, niemieckiego korespondenta prasowego, który dzięki obrazom malarza uświadamia sobie, czym jest poszukiwana przez niego prawda o Polsce - kraju jego urodzenia (Waniek 2016: 338-341). 
zbiorowej świadomości. Browarny zalicza te książki do „narracji o polskiej odpowiedzialności i wstydzie za degradację Gór Śląskich" (Browarny 242). Zwraca uwagę na to, że Waniek pisze o historycznej przynależności ziem śląskich do innej, tzn. zachodniej cywilizacji, i klęsce jej osiągnięć po 1945 roku. Śląsk stanowił bowiem nie tylko pogranicze z sąsiednimi państwami, ale był też zdaniem pisarza krainą bliższą kulturze zachodniej niż pozostałe regiony Polski. „Tutaj pobliże cywilizacji europejskiej wyczuwało się silniej niż w rdzennej głębi kraju" (Waniek 2006: 5). Nie prowadzi to jednak autora do narodowych resentymentów czy historycznych rozliczeń, bowiem potrzeba sprawiedliwego osądu XX-wiecznych dziejów regionu wiedzie do próby włączenia przeszłości w żywą teraźniejszość.

Na pierwszy plan w literackiej twórczości Wańka wysuwa się zagadnienie pamięci. Spośród kilku rozpowszechnionych we współczesnej nauce teorii pamięci chciałabym do wyjaśnienia fenomenu pamiętania przeszłości w jego śląskich książkach przywołać koncepcję miejsc pamięci. Wedle jej twórcy, Pierre'a Nory, pamięć tworzy historię drugiego stopnia (Traba, Hahn 16) ${ }^{20}$. W latach dziewięćdziesiątych koncepcja ta zyskała znaczny rezonans w naukach społecznych i humanistycznych. Następnie Hagen Schulze i Etienne François w książce Deutsche Erinnerungsorte (München 2001) doprecyzowali zakres znaczeniowy tej kategorii, twierdząc, że "miejsce pamięci" jest metaforą o sensie o wiele szerszym niż tylko przestrzenny, jest toposem w dosłownym znaczeniu. Miejsca pamięci mogą istnieć w sposób materialny i niematerialny, bowiem:

należą do nich i realne, i mityczne postacie i zdarzenia, budynki i pomniki, instytucje i pojęcia, książki i dzieła sztuki. [...] Chodzi o długotrwałe, konstytutywne dla wielu pokoleń punkty krystalizacyjne pamięci zbiorowej i tożsamości, które stanowiąc część społecznych, kulturowych i politycznych zwyczajów, zmieniają się w zależności od tego, jak zmienia się ich postrzeganie, przyswajanie, używanie i transponowanie (Schulze, François 17, cyt. za: Traba, Hahn 10).

Uwzględniając powyższe, należy powiedzieć, że Śląsk jest niezwykle bogatym miejscem pamięci dwu narodów: polskiego i niemieckiego. To samo miejsce nie oznacza wszakże wspólnej pamięci. Wydaje się, że Waniek występuje jako obrońca pamięci przeszłych, niemieckich mieszkańców Śląska oraz kultury, którą stworzyli. Należy to rozumieć jako dążenie nie do jednostronnego oglądu, lecz jedynie

20 Naukowy namysł nad kategorią miejsc pamięci jest kontynuacją badań nad pamięcią zbiorową, zainicjowanych w 1925 roku przez francuskiego socjologa Maurice'a Halbwachsa. W polskim dyskursie naukowym dopiero od kilku lat pojawiają się publikacje na temat "miejsc pamięci” oraz "kultury pamięci”, rozpowszechnionej zwłaszcza w Niemczech dzięki pracom Jana i Aleidy Assmannów. Zob. np. monumentalny dwujęzyczny cykl Polsko-niemieckie miejsca pamięci, red. R. Traba, H.H. Hahn, M. Górny, K. Kończal, t. 1-9, Warszawa/Paderborn 2012-2015; Pamięć zbiorowa i kulturowa. Wspótczesna perspektywa niemiecka, red. M. Saryusz-Wolska, Kraków 2009; Modi memorandi. Leksykon kultury pamięci, red. M. Saryusz-Wolska, R. Traba, Warszawa 2014. 
do przywrócenia należnego im miejsca w historii regionu. Autorowi towarzyszy świadomość, iż kataklizm II wojny i następujące po nim dziesięciolecia PRL-owskiej polityki historycznej, polegającej na wybiórczym traktowaniu przeszłości w imię aktualnych potrzeb politycznych, wymagają od twórcy odpowiedzialności. Historia nałożyła na artystów pewne zobowiązanie. W omawianych książkach polega ono na nakazie odpominania i pamiętania. Pisarz przyjmuje na siebie rolę strażnika pamięci, odkrywającego i kultywującego prawdę o śląskiej ziemi, jej przeszłości i wielowiekowej koegzystencji przedstawicieli różnych narodów, których dorobek złożył się na niepowtarzalną całość stanowiącą o kulturowej specyfice Śląska.

Waniek scala umiejętnie dwa plany narracyjne, związane z pamięcią jednostkową oraz pamięcią zbiorową. Browarny następująco charakteryzuje sposób, w jaki artysta konstruuje oddziałujące na siebie nawzajem pamięć biograficzną i monumentalną:

Jego opowieść jest mitotwórcza, zarazem oparta na osobistym doświadczeniu, ale i kreacyjna, gdyż to doświadczenie wykracza poza świat empiryczny i egzystencję. Autor łączy oba wymiary pamięci w ten sposób, że wychodząc od realnej biografii, wkracza w sferę kultury symbolicznej i mitu lokalnego, które indywidualnym przeżyciom nadają znaczenie ponadjednostkowe. $Z$ drugiej strony przestrzeń, historia i tradycje Sudetów są ożywiane poprzez ich "czytanie" w perspektywie osobistej (Browarny 256).

Książki eseistyczne i powieści Wańka zbliża do siebie konstrukcja podmiotu-wędrowcy, protagonisty autobiograficznie utożsamianego z autorem, przekraczającego swobodnie granice nie tylko w przestrzeni, ale i w czasie. Na przykład w powieści Finis Silesiae, której akcja rozpoczyna się w 1937 roku i trwa do końca wojny, tożsamy z autorem narrator ujawnia swą obecność, dzieląc się wiedzą, jaką dysponuje dzisiaj. Zdradza, co zdarzyło się kilkadziesiąt lat później, jak zmieniały się przedstawiane miejsca, ujawniając tym samym, że opisuje świat, do którego nigdy nie należał. Wyraźnie zaznaczony dystans narracji, fakt, że narrator znajduje się na zewnątrz świata przedstawionego, umożliwia swobodne pokonywanie różnic czasowych. Tego rodzaju rozdwojenie podmiotu sprawia, że ma on - zgodnie z typologią przedstawioną przez Ryszarda Nycza - charakter sylleptyczny w jego drugim, egzystencjalnym wariancie, a zatem należy go rozumieć równocześnie jako "ja” empiryczne i ,ja” tekstowe, autentyczne i fikcyjne (Nycz 49-50). Oznacza to specyficzną relację podmiotu i tekstu, która przyjmuje charakter interferencji, dwukierunkowego oddziaływania.

Pisarz ukazuje Śląsk w całym jego kulturowym bogactwie i historycznej złożoności jako polsko-niemiecko-czeskie pogranicze. Magdalena Rabizo-Birek trafnie zauważa, że

Opis podróży mistycznej... nie ukazuje losów konkretnych narodów, lecz jest "opowieścią o ludziach, których połączyło ponad wiekami zamieszkiwanie na tej samej ziemi. 
Porozumienie między Polakami, Czechami, Niemcami, Ślązakami zamieszkującymi Śląsk w różnych okresach dokonuje się w jego książce dzięki samemu faktowi [...] podlegania działaniu szczególnego klimatu, a więc wszystkiemu co mieści się w pojęciu genius loci - fenomenu miejsca" (Rabizo-Birek 1997:114).

Z tego powodu czymś bezcelowym i anachronicznym jest jednowymiarowa, podbudowana ideologicznie pamięć etniczna, „nieproduktywna w stosunku do terenów o palimpsestowej przeszłości" (Browarny 242-243). Ponieważ książki Wańka rozgrywają się na etniczno-kulturowym pograniczu, warto zwrócić uwagę na charakterystyczną dla takich obszarów odmienność, ale i nakładanie się na siebie perspektyw narodowych, w tym wypadku głównie polskiej i niemieckiej. Autor dystansuje się od tej opozycji, zastępując ją śląską świadomością regionalną. Chodzi tu o

pamięć śląskocentryczną i pamięć europocentryczną, które Waniek integruje kosztem panującej przez powojenne dekady narracji polskocentrycznej. [...] Autor ciągle z nią dialoguje, kwestionując jednak jej status opowieści bazowej - metabytu, który określa sens i wartość wszystkich innych pamięci miejsca (Browarny 256).

W tym kontekście należy podkreślić koncyliacyjny ton jego utworów. Autor, moim zdaniem, w kolejnych książkach rozwija i precyzuje swój - jak można by go zapewne nazwać - ponadnarodowy „wielki projekt”, dotyczący przywracania i reinterpretowania przeszłości oraz jej wprowadzania do teraźniejszości i przyszłości. Przyjmuje przy tym perspektywę humanistyczną - nie partykularną, narodowo-etniczną, lecz ogólnoludzką. Według Browarnego, Waniek

redukuje pamięć zbiorową na rzecz kulturowej, tzn. uwalnia dzieje lokalne od uproszczeń i narodowych pretensji, a w zamian [...] wpisuje w przeszłość miejsca uniwersalną wspólnotę, w której mogą uczestniczyć też współcześni; naturalnie tylko wybrani. Autor, akcentując dystans do etyki i historii jako stanów świadomości kolektywnej, proponuje czytelnikom porozumienie estetyczne. Nie projektuje żadnej społecznej rzeczywistości dla wszystkich. [...] Tożsamość szkicowana w esejach Wańka jest elitarna i ulotna, pochwytna jedynie w książkach, ideach i pamięci kulturowej (Browarny 257-258).

Wypada zasadniczo zgodzić się z powyższymi słowami badacza, z jednym wszakże zastrzeżeniem: pamięć kulturowa jest pamięcią zbiorową, zatem zastosowane powyżej rozróżnienie budzi pewne wątpliwości, które rozwiać może przypomnienie koncepcji pamięci kulturowej Assmanna (Assmann 2008) ${ }^{21}$.

21 Pamięć kulturowa to, wedle Assmanna, pojęcie nadrzędne w stosunku do pamięci jednostkowej, odnosi się do sfery ponadindywidualnych, zinstytucjonalizowanych mechanizmów transmisji spo- 
Żywioł historii jest $\mathrm{w}$ tej prozie wszechobecny. Jak zauważa bohater Finis Silesiae Paul Scholz, „moim ulubionym kierunkiem jest przeszłość. Tam wszystko jest pewne i zrobione" (Waniek 2003: 214). Narracje Wańka są przedstawieniem „długiego trwania" kultury śląskiej, które ma ogromne znaczenie dla współczesności. Pisarz eksploruje przeszłość śląskich miejsc, pojmując ją jako dziedzictwo będące zobowiązaniem. Dziedzictwo zobowiązuje do pamiętania. Pisarzowi chodziło między innymi o docieranie do prawdziwej historii Śląska, na przekór zafałszowaniom oficjalnej propagandy i historiografii: „Zrazu mieliśmy więc tylko mglistą świadomość bogactwa tutejszych tradycji. Łatwo to zrozumieć, skoro po roku 1945 Polska narzuciła Śląskowi wersję historii wyssaną z palca, odrażająco fałszywą i pozbawioną kulturalnych korzeni" (Waniek 2006: 5). Toteż pisarz stawia przed sobą zadanie poszukiwania prawdy o Śląsku i jego dziejach. W takim ujęciu literatura staje się medium pamięci.

\section{2.}

Artysta w swej twórczości wielokrotnie dawał wyraz przekonaniu o mistycznej naturze otaczającego świata. W szkicu pt. Mistyczna aura Śląska, wspominając działalność Kręgu Oneiron, pisał: „Powołaniem artysty jest obcowanie z tym, co ukryte. Można oczywiście uprawiać sztukę bez tajemnicy i tak czyni większość. My natomiast chcieliśmy stworzyć wyłom w spętanej powszedniości" (Waniek 2006: 5). Koncepcja rzeczywistości zakładająca istnienie tajemnicy, wiodąca do odkrywania tego, co ukryte, dotyczyła nie tylko sposobu uprawiania sztuki, ale też okazała się ściśle związana z konkretnym miejscem, narodziła się bowiem na Śląsku: „Gruntem naszego porozumienia była mistyka i zrazu nie postrzegaliśmy faktu, że sens naszych działań jest także związany z konkretnym tłem geograficznym; że to wszystko nie mogło się zdarzyć gdzie indziej niż na Śląsku" (Waniek 2006: 5).

Poszukiwanie motywów mistycznych w przedstawianej rzeczywistości pozostało trwałym rysem twórczości literackiej i malarskiej Wańka. Jego podróże po Śląsku nie znają granic przestrzeni ani czasu - pisarz nie dzieli Śląska na Górny i Dolny, traktuje go jako całość, czego wyrazem jest tytuł jednej z książek eseistycznych: Opis podróży mistycznej z Oświęcimia do Zgorzelca 1257-1957. Jego zdaniem ludowy mistycyzm jest jedną z najważniejszych cech kultury Śląska, emanacją jego genius loci. Przez całe wieki śląskie góry i ich skarby, bogactwa mineralne, przyciągały uwagę „europejskiej elity nauk tajemnych” (Waniek 1995: 63-64). Pisarz sięga do dawnych podań na temat Sudetów, gdzie szukali schronienia Łużyczanie uchodzący w X wieku przed naporem chrześcijaństwa, którzy mieli tu założyć nowy ośrodek

łecznej pomiędzy generacjami w danej społeczności. Tak pojmowana pamięć kształtuje wtórnie świadomość jednostek, wprowadzając je w zakres tego, co wspólnota chce przechować. Pamięć jest też nadrzędna w stosunku do historii, ponieważ „historia to rezultat działania i pamiętania. Historia jest nam dana wyłącznie przez pamięć, a to, co się dzieje, zostaje zapamiętywane tylko jako działanie" (Assmann 243). 
kultu swego boga Flinsa. W późniejszych czasach Walonowie poszukiwali skarbów, w śląskie góry uciekali przed prześladowaniami religijnymi między innymi ewangelicy w okresie kontrreformacji. Śląski mistycyzm wytworzyć się miał dzięki temu, że region jest, jak to trafnie ujął Sergiusz Sterna-Wachowiak, alchemicznym

tyglem narodów, kultur i wyznań czynnym długie wieki, podczas których usiłowano zapośredniczyć ziemię $\mathrm{w}$ niebie albo chociaż sprowadzić niebo na ziemię, choćby pod postacią Nowego Jeruzalem w Wambierzycach, a Nowego Syjonu we Wschowie (Sterna-Wachowiak 26).

Duchowa strona rzeczywistości przyjmuje w tej twórczości ucieleśnienie w postaci lokalnych duchów, bóstw i demonów. Stają się one miejscami żywej pamięci. Przypomnijmy, że miejsca pamięci istnieją nie tylko na mapie czy w realnej przestrzeni, ale mogą istnieć także w sposób niematerialny, ponieważ „należą do nich i realne, i mityczne postacie i zdarzenia, [...] pojęcia, książki i dzieła sztuki. [...] Chodzi o długotrwałe, konstytutywne dla wielu pokoleń punkty krystalizacyjne pamięci zbiorowej i tożsamości" (Schulze, François 17, cyt. za: Traba, Hahn 10). Nie są to więc tylko wydarzenia historyczne, ważne postacie dziejowe, lecz także fenomeny kulturowe czy nawet wytwory wyobraźni. Do tak rozumianej śląskiej spuścizny memorialnej wspólnej dla obydwu narodów należy Rübezahl-Liczyrzepa. Analogiczne pod pewnymi względami miejsca pamięci dwu narodów często jednak pełnią w ich tożsamości zbiorowej odmienne funkcje.

Rübezahl i Flins, istoty nie-ludzkie, choć bliskie człowiekowi, są według legend potężnymi demonami, nie zdołały wszakże ochronić swej krainy przed zniszczeniem. Pierwszy, po wojnie przemianowany przez polskich krajoznawców na Liczyrzepę (Sykulski) ${ }^{22}$, jest duchem opiekuńczym Karkonoszy, drugi natomiast, łużycki bóg śmierci i odrodzenia, utracił wówczas swe miasto (Bad Flinsberg) wyparty przez chrześcijańskiego świętego Świerada, który dla politycznych decydentów okazał się bardziej akceptowalny niż bóstwo przedwojennych mieszkańców kurortu.

Bóstwa i demony także wyklęto i wypędzono - przede wszystkim z pamięci i toponimii regionu - razem z Niemcami i Łużyczanami. [...] Chrystianizację kultury Słowian zachodnich, rozpoczętą przez germańskich władców w średniowieczu, dokończyli po 1945 roku - znowu w sojuszu ołtarza i tronu - polscy katolicy i komuniści (Browarny 248).

U Wańka Flins pełni rolę ducha dziejów, patronuje bowiem historiozofii regionu, w którego dziejach upadek i kulturowy schyłek przeplatają się z odrodzeniem i wzrostem. (Browarny 248)

22 Autorem spolszczenia oryginalnej nazwy Rübezahl był Józef Sykulski, który zaraz po wojnie wydał broszurę zatytułowaną Liczyrzepa, zły duch Karkonoszy i Jeleniej Góry (Jelenia Góra 1945). 
Śląski mistycyzm nie sprowadza się oczywiście tylko do ludowych podań i legend o duchach, do opowieści o poszukiwaczach skarbów i alchemikach, lecz bodaj najmocniej wyraża się on w bogatej tradycji mistycznej, wypracowanej przez szereg znaczących śląskich myślicieli, których pisarz uczynił duchowymi patronami swych wędrówek po Śląsku i jego historii. Wiele uwagi poświęca on Johannesowi Schefflerowi, zwanemu Aniołem Ślązakiem, który jest też przykładem śląskiej wielokulturowości. Śląskim mistykom autor poświęcił dużo miejsca w swoich książkach, zwłaszcza w tej pod wymownym tytułem Opis podróży mistycznej z Oświęcimia do Zgorzelca 1257-1957. Towarzyszą mu Mikołaj z Oświęcimia, Angelus Silesius i Ahaswer - Żyd Wieczny Tułacz. Postacie historyczne, na przykład Scheffler, stają się przewodnikami narratora, jakby na wzór Boskiej komedii Dantego. Inną wielką postacią śląskiego baroku w niemieckiej kulturze, która fascynuje pisarza, jest Jakub Böhme. Paul Scholze w Finis Silesiae oprowadzający Brigitte po Zgorzelcu przywołuje słowa swego wykładowcy, docenta Peuckerta, który uważał, że pisma mistyczne Böhmego zawierają znaczenia, których zabrakło w Biblii, i że zgorzelecki szewc dopisał brakujące części Księgi Genesis (Waniek 2003: 261). Pisarz charakteryzuje śląskiego mistyka jako „istotę z geograficznego i duchowego pogranicza. Przekraczając tę granicę w porywach mistycznego uniesienia, zajmował się - jak to z mieszkańcami pogranicza bywa - przemytem wiedzy o tamtej stronie rzeczywistości" (Waniek 1996: 101). W czasach Böhmego Śląsk był ośrodkiem silnego oddziaływania zwolenników Paracelsusa. Jak zauważa Jarosław Petrowicz, „nie przypadkiem u Wańka pojawiają się takie postacie jak Paracelsus, Hermes Trissmegistos, autor idzie bowiem śladami śląskich mistyków. [...] Zasadą rzeczywistości okazuje się życie i ruch. Sama wyobraźnia zaś ma moc magiczną" (Petrowicz 188). Konstatacja ta koresponduje ze wskazanym w pierwszej części artykułu bliskim artyście związkiem sztuki i magii.

Charakterystyczne dla obszarów pogranicza zmiany przebiegu granic wiążą się z historycznym zjawiskiem wysiedleń - nie tylko dotychczasowych mieszkańców, ale także śladów ich kulturowego dorobku oraz z wymazywaniem wszelkiej pamięci o nich. $\mathrm{W}$ ten sposób cały Śląsk staje się w prozie Wańka, zgodnie z tytułem jednego z utworów, „cmentarzem nieśmiertelnych”, których pisarz - wbrew celowemu zapomnieniu, świadomej degradacji w powojennych dziesięcioleciach oraz przemijaniu czasu i obojętności współczesnych - pragnie przywrócić do żywej pamięci i którym chce oddać należne im miejsce w kulturowym panteonie Śląska. Nie chodzi jednak tylko o to, by przeszłych mieszkańców nieco sentymentalnie „ocalić od zapomnienia". Idzie o to, by - na przekór niełaskawej historii i inercji upływającego czasu - przywrócić "nieśmiertelnych” do świata żywych, by „przekraczać dystans czasu i narodowych uprzedzeń, zmieniając cudzą przeszłość we wspólną teraźniejszość" (Browarny 249). Jak bowiem stwierdził pisarz w jednej z pierwszych książek: „Kluczem do teraźniejszości jest przeszłość” (Waniek 1997: 6). 
W Cmentarzu nieśmiertelnych Waniek przezwycięża pesymistyczną wizję Śląska zawartą w Finis Silesiae, w której ukazał brutalny kres niemieckiej formacji kulturowej na Śląsku, unicestwionej nie tylko przez działania wojenne, ale też bezrozumnie niszczonej przez powojennych osiedleńców i ich potomków. W nowszej książce pojawiają się nuty optymizmu. Świadomość schyłku została zastąpiona przez przeświadczenie o wiecznej zmianie, w której po doświadczeniach kresu następuje przemiana i odrodzenie. Rzec można, iż zgodnie z Eliadowskimi kategoriami czasu świeckiego i świętego (Eliade) zmienności charakterystycznej dla czasu historycznego towarzyszy trwały czas mityczny, którego wyrazicielem jest u Wańka śląski genius loci. Współwystępowanie dwóch porządków czasowych, historycznego i mitycznego, wpływa na takie ukształtowanie świata przedstawionego, dzięki któremu zyskuje on głębszy wymiar, a perspektywa materialna i duchowa nakładają się na siebie. Jak trafnie napisał Petrowicz, "Śląsk Henryka Wańka to dziedzina przeżycia mistycznego, świat realiów jest jednocześnie przestrzenią duchową" (Petrowicz 160).

\section{3.}

Waniek najchętniej wypowiada się w formie eseju. Większość jego literackiego dorobku ma charakter eseistyczny, lecz nie brakuje w nim także powieści, z których największy rozgłos zasłużenie zdobyła Finis Silesiae. Alois Woldan zwraca uwagę na trzecią, pośrednią formę gatunkową śląskich utworów Wańka (Woldan 1), którą można by, jak sądzę, nazwać fabularyzowanym esejem, inaczej niż klasyczny esej zawiera on bowiem jakąś fabułę. Jego utwory są najczęściej zapisem rzeczywistej lub imaginacyjnej wędrówki. Nie są one jednak przykładami "czystego" podróżopisarstwa, ponieważ - jak zauważa Woldan - „nie są to opisy tego, co widzi się na poszczególnych etapach drogi, lecz tego, co jest rekonstruowane, to znaczy wydarte przeszłości" (Woldan 2).

Pisarz w swych książkach z upodobaniem posługuje się opowieścią wspomnieniową, włączaną do głównego toku narracji, a także biografią inkrustowaną anegdotami. W taki sposób kreuje w Cmentarzu nieśmiertelnych (Waniek 2015) portret karkonoskiej kolonii twórców osiadłych na przełomie XIX i XX wieku w Szklarskiej Porębie. Utwór ten to powieść o artystach połączona z motywami legendarnymi (Browarny 253). W śląskich książkach pojawiają się też ekfrazy fotografii (jak w Finis Silesiae, gdzie cykl fotografii krajobrazów Śląska pełni rolę fabularnej osnowy, jako że bohaterowie wędrują trasą wyznaczoną przez miejsca uwiecznione na poszczególnych zdjęciach) oraz obrazów, wśród których wyjątkową rolę pełnią panoramy Caspara Davida Friedricha. Ten romantyczny niemiecki malarz, znany z niezwykłych pejzaży ukazujących dramatyczny teatr natury oraz z obrazów analizujących stosunek człowieka i przyrody, należy do ulubionych malarzy Wańka. Najsłynniejsze dzieła Friedricha powstały na Rugii, ale artysta ten odwiedzał ze szkicownikiem także Riesengebirge (Karkonosze), o czym świadczą na przykład prace powstałe 
około 1810 roku: akwarela znana jako Widok Karkonoszy czy płótno Poranek w Karkonoszach (Bałus 110)23. Pisarz snuje o nim refleksje w kilku szkicach zamieszczonych w tomie Martwa natura z niczym. Elżbieta Dutka zwraca uwagę na to, iż „niemiecki artysta na swoich obrazach przedstawiał postaci odwrócone tyłem do widza, zapatrzone w przedstawiony krajobraz i kierujące na niego całą uwagę oglądających" (Dutka 248). Analogicznie wykadrowane zostały zdjęcia umieszczone i omawiane w Finis Silesiae. Jej bohater wskazuje Friedricha jako ulubionego malarza, mówiąc: "To mistrz krajobrazu. Znawca utajonej w nim świętości” (Waniek 2003: 245). Jego słowa wskazują na szczególny, kontemplacyjny stosunek do pejzażu, łączący postawę emocjonalną z intelektualnym namysłem.

Można by uznać bez wielkiego ryzyka błędu, że Waniek należy do postromantycznego nurtu polskiej sztuki jako twórca prowadzący samodzielne poszukiwania na temat miejsca człowieka w świecie, jego relacji wobec natury oraz ukazujący kreacje bohaterów jako indywidualistów i buntowników. Wędrując po śląskich górach i dolinach, podmiot Wańka uruchamia romantyczny topos czytania w księdze natury. Jest ona dla niego nie tylko scenerią, na której tle dzieje się historia. Podąża zatem śladami alchemików, geomantów, karkonoskich laborantów, przypominając towarzyszące im bóstwa i duchy miejsc. Pisarz pojmuje drogę jako tekst, rozumie ją jako niekończący się epos, "analfabetyczną literaturę", uznaje ją za „wzorcowy przekaz hermetyczny" (Waniek 1995: 71). Także góry postrzega jako obszar wiedzy tajemnej, uważa, że są „napisanym przez samą naturę traktatem filozoficznym. Można go, znając odpowiedni język, studiować" (Waniek 1995: 71).

Fabuła Finis Silesiae oparta została na motywie podróży. Główny bohater Paul Scholze pokazuje ukochanej Brigitte najpiękniejsze miejsca na Śląsku, który przemierzają ze wschodu na zachód. Będąc na zamku Gryf, bohaterka „zobaczyła stamtąd obraz przede wszystkim niewyrażalnie piękny. Ale dla Paula był to najbardziej treściwy optyczny poemat; palindrom dający się czytać we wszystkie strony świata" (Waniek 2003: 274). Pejzaż staje się więc tekstem, który dzięki wprawnemu, uważnemu spojrzeniu można czytać. Szczególnie ważna jest kreacja przestrzeni tego świata, który autor traktuje jako księgę. Tekstem do odczytania staje się mapa albo widok okolicy oglądanej z góry. „Natura ukazuje bohaterom swe piękno, dzięki rozumiejącej myśli wychodzi z ukrycia" (Petrowicz 174). Kreacja głównego bohatera jako artysty-fotografika, przemierzającego Śląsk z aparatem, umożliwiła ukazanie piękna krajobrazu i terapeutycznych efektów obcowania z przyrodą. W książce tej ożywają romantyczne koncepcje natury i prądy mistyczne rozpowszechnione w Niemczech od końca XIX wieku, takie jak teozofia, antropozofia, panteizm. Dzię-

23 Analiza akwareli znajduje się w pracy Wojciecha Bałusa, który stwierdza: „Friedrich [...] malował przez całe życie jeden obraz. Celem jego było uchwycenie jakiejś symbolicznej treści świata, relacji stworzenia do Boga i Boga do stworzenia oraz miejsca człowieka w całym tym konglomeracie" (Bałus 111). 
ki kontaktowi z naturą bohaterowie doznają wewnętrznego oczyszczenia i odnowy. Otwierając się na świat, czują, że zbliżają się do sacrum ${ }^{24}$.

Zwraca uwagę głębokie zaangażowanie emocjonalne pisarza w przedstawianie śląskiej problematyki. Rabizo-Birek nazywa go "górnikiem śląskiej kultury, odsłaniającym jej bogate, a ukryte lub zapomniane pokłady" (Rabizo-Birek 1998: 118). Ta odwołująca się do geologii metafora służy do określenia sposobu, w jaki pisarz eksploruje teksty kultury. Wiedza o przeszłości regionu została zapisana między innymi w języku, który go opisuje. Waniek podaje szereg przykładów praktyki onomastycznej zmierzającej do symbolicznego zawłaszczania krainy przez kolejne władze państwowe. Ukazuje manipulacje językowe i przemianowywanie rzeczywistości za pomocą nowomowy, rozwijanej przez rzeszę tzw. Quellenforscherów, o czym świadczy na przykład historia nazwy góry Ślęży (Waniek 2003: 252). Ten sam mechanizm powtórzy się, gdy po wojnie zajmą te ziemie przedstawiciele Polski Ludowej. Pisarz dobrze wie o tym, że nazwy własne pełnią w tekście funkcję tropów toponomastycznych, tworząc w ten sposób dyskurs pamięciowy (Rybicka 195-197).

Jak wynika z powyższych rozważań, Waniek pozostał wierny problematyce odkrytej na początku drogi twórczej. Nieustannie rozwija ją i pogłębia. Pisarz łączy w swej sztuce - jak była mowa na początku - przeciwstawne modele, outsiderski i powinnościowy, przechodząc od dominującego w początkowym okresie twórczości modelu artysty skoncentrowanego na zagadnieniach estetyki do modelu odpowiedzialności za rzeczywistość, szczególnie tę najbardziej autora interesującą, związaną ze Śląskiem i jego historyczną spuścizną, istotną dla współczesności i przyszłości. W trwającej już ponad pół wieku działalności twórczej udało mu się zachować wewnętrzną autonomię i konsekwentnie podążać własną drogą.

\section{BIBLIOGRAFIA}

Abraham Ralph, McKenna Terrence, Sheldrake Rupert. Zdążý przed Apokalipsą. Przeł. Sławomir Studniarz. Bydgoszcz: Limbus, 1995.

Assmann, Jan. Pamięć kulturowa. Pismo, zapamiętywanie i polityczna tożsamość w cywilizacjach starożytnych. Przeł. Anna Kryczyńska-Pham. Warszawa: Wydawnictwa Uniwersytetu Warszawskiego, 2008.

Bałus, Wojciech. „Osiągalne - nieosiągalne. O topografii symbolicznej obrazów z motywem krzyża w twórczości Caspara Dawida Friedricha". Miejsce rzeczywiste. Miejsce wyobrażone. Studia nad kategoria miejsca w przestrzeni kultury. Red. M. Kitowska-Łysiak, E. Wolicka. Lublin: Towarzystwo Naukowe KUL, 1999. S. 107-128.

24 Waniek nawiązuje do historycznego zjawiska. Paul i jego towarzysze, wędrujący w latach trzydziestych XX wieku po górach czy słuchający przy ognisku rozważań antropozofa Webera (a pojawiają się też nazwiska Rudolfa Steinera i Wilhelma Bölschego), są reprezentantami autentycznego ruchu miłośników natury, którego zwulgaryzowaną mutacją była „blubo”, o czym pisałam przy innej okazji (Ćwiklak 54-78). 
Breton, André. „Drugi manifest surrealizmu”. Surrealizm. Teoria i praktyka literacka. Antologia. Wyb. i przeł. Adam Ważyk. Warszawa: Czytelnik, 1976. S. 125-148.

Browarny, Wojciech. „Sudety wyklęte. Pamięć Gór Śląskich w polskim eseju, reportażu i literaturze historyczno-krajoznawczej XXI wieku". Regionalizm literacki - historia i pamięć. Red. Z. Chojnowski, E. Rybicka. Kraków: Universitas, 2017. S. 241-259.

Ćwiklak, Kornelia. Bliscy nieznajomi. Górnoślaskie pogranicze w polskiej i niemieckiej prozie wspótczesnej. Kraków: Universitas, 2013.

Dutka, Elżbieta. Próby topograficzne. Miejsca i krajobrazy w literaturze polskiej XX i XXI wieku. Katowice: Wydawnictwo Uniwersytetu Śląskiego, 2014.

Eliade, Mircea. "Czas święty i mity”. Sacrum, mit, historia. Przeł. Anna Tatarkiewicz. Warszawa: Państwowy Instytut Wydawniczy, Warszawa 1993. S. 89-125.

Mraß, Peter. „Gry wyobraźni. O projekcie Czarnych Kart /Spiele der Vorstellungskraft. Über das Projekt der Schwarzen Karten". Oneiron. Ezoteryczny krąg artystów z Katowic. Ein esoterischer Künstlerkreis aus Kattowitz [edycja dwujęzyczna]. Red. P. Mraß. Przeł. Jacek Mraß. Katowice: Wydawnictwo KOS, 2006. S. 13-29.

Nora, Pierre. Les lieux de memoire. T. 1-7. Paris: Gallimard, 1984-1992.

Nycz, Ryszard. „Tropy „ja”. Koncepcje podmiotowości w literaturze polskiej ostatniego stulecia”. Ja, autor. Sytuacja podmiotu w polskiej literaturze wspótczesnej. Red. D. Śnieżko. Warszawa: Wydawnictwo Naukowe Semper, 1996. S. 38-57.

Oneiron. Ezoteryczny krąg artystów z Katowic (BWA Karkonosze, Jelenia Góra, 29.11.2006 -15.01.2007) [Wstęp do katalogu wystawy]. Web. 20.09.2018 <http://galeria-bwa.karkonosze.com/oneiron-ezoteryczny-krag-artystow-z-katowic>.

Petrowicz, Jarosław. Zwiazek z miejscem. Ślask historyczny w prozie, eseistyce i reportażu polskim po 1989 roku. Wieluń: Wieluńskie Towarzystwo Naukowe. Muzeum Ziemi Wieluńskiej, 2015.

Rabizo-Birek, Magdalena. „Mądrość śląskiego szarlatana”. Twórczość 7 (1997). S. 112-115.

Rabizo-Birek, Magdalena. „Waniek na trawie”. Twórczość 2 (1998). S. 118-119.

Rybicka, Elżbieta. Geopoetyka. Przestrzeń i miejsce we wspótczesnych teoriach i praktykach literackich. Kraków: Universitas, 2014.

Schulze Hagen, François Etienne. Deutsche Erinnerungsorte. München: C. H. Beck Verlag, 2001.

Sterna-Wachowiak, Sergiusz. „Kartophilos w mistycznej podróży”, Nowe Książki 11 (1996). S. 26.

Radziwon, Marek. „Śląsk z zaświatów”. Z H. Wańkiem rozmawiał M. Radziwon. Gazeta Wyborcza 221 (2004). S. 15

Stuchlik, Zygmunt. „Wśród ludzi wolnych w kraju podległym”. Katowicki underground artystyczny po 1953 roku. Red. J. Zagrodzki. Katowice: Galeria Sztuki Współczesnej BWA w Katowicach, 2004. S. 187-189.

Sykulski, Józef. Liczyrzepa, zły duch Karkonoszy i Jeleniej Góry. Jelenia Góra: Księgarnia ZLP, 1945.

Traba Robert, Hahn Hans Henning, red. Polsko-niemieckie miejsca pamięci. T. 3. Paralele. Warszawa: Wydawnictwo Naukowe Scholar, 2012.

Urbanowicz, Andrzej. „Śladami Chaosu”. Opcje 3 (1996). S. 87-91.

Urbanowicz, Andrzej. „Sztuka jako narzędzie rewolucji wewnętrznej”. Katowicki underground artystyczny po 1953 roku. Red. J. Zagrodzki. Katowice: Galeria Sztuki Współczesnej BWA w Katowicach, 2004. S. 91. 
Urbanowicz, Andrzej. „Dotknięcia. Ślady / Berührungen. Spuren”. Oneiron. Ezoteryczny krąg artystów $z$ Katowic. Ein esoterischer Künstlerkreis aus Kattowitz [edycja dwujęzyczna]. Red. P. Mraß. Przeł. Jacek Mraß. Katowice: Wydawnictwo KOS, 2006. S. 30-175.

Waniek, Henryk [hasło w:], Polscy pisarze i badacze literatury przełomu XX i XXI wieku. Web: 01.09.2018 <http://www.ppibl.ibl.waw.pl/mediawiki/index.php?title=Henryk_WANIEK>.

Waniek, Henryk. „Nie znany mi bliżej Bellmer”. NaGłos 15/16 (1994). S. 218-226.

Waniek, Henryk. Hermes w górach ślaskich. Wrocław: Wydawnictwo Dolnośląskie, 1995.

Waniek, Henryk. Opis podróży mistycznej z Oświęcimia do Zgorzelca 1257-1957. Kraków: Znak, 1996.

Waniek, Henryk. „Przeciw ubezwłasnowolnieniu. Oneiron”. Katowicki Underground artystyczny po 1953 roku. Red. J. Zagrodzki. Katowice: Galeria Sztuki Współczesnej BWA w Katowicach, 2004. S. 173-182.

Waniek, Henryk. „Mistyczna aura Śląska / Schlesiens mystische Aura”. Oneiron. Ezoteryczny krąg artystów z Katowic. Ein esoterischer Künstlerkreis aus Kattowitz [edycja dwujęzyczna]. Red. P. Mraß. Przeł. Jacek Mraß. Katowice: Wydawnictwo KOS, 2006. S. 4-11.

Waniek, Henryk. Cmentarz nieśmiertelnych. Kolonia pisarzy i innych takich. Wrocław: Ośrodek Kultury i Sztuki we Wrocławiu, 2015.

Waniek, Henryk. Obcy w kraju urodzenia. Kotórz Mały: Silesia Progress, 2016.

Woldan, Alois. „Śląsk mityczny - uwagi o śląskiej prozie Henryka Wańka”. Przeł. Jürgen Herzog. Fraza - Poezja. Proza. Esej 1-2 (2015). Web: 30.09.2018<http:// fraza.univ.rzeszow.pl/teksty_naukowe/A.-Woldan-Slask-mityczny--uwagi-o-prozie-Henryka-Wanka.pdf>.

Zagrodzki Janusz, red. Katowicki underground artystyczny po 1953 roku. Katowice: Galeria Sztuki Współczesnej BWA w Katowicach, 2004. 